\title{
Suppression of Avocado (Persea americana Mill.) Fruit Softening and Changes in Cell Wall Matrix Polysaccharides and Enzyme Activities: Differential Responses to 1-MCP and Delayed Ethylene Application
}

\author{
Jiwon Jeong and Donald J. Huber ${ }^{1}$ \\ Horticultural Sciences Department, Institute of Food and Agricultural Sciences, University of Florida, \\ 1213 Fifield Hall, Gainesville, FL 32611
}

\begin{abstract}
ADDitional INDEX WORDS. alpha-galactosidase, beta-galactosidase, endo-1,4-beta-glucanase, galactose, 1-methylcyclopropene, pectinmethylesterase, polygalacturonase, polyuronide

Abstract. Pre-ripe 'Booth 7' avocado (Persea americana Mill.) fruit, a cross of West Indian and Guatemalan strains, were treated with $0.9 \mu \mathrm{L} \cdot \mathrm{L}^{-1} 1$-methylcyclopropene (1-MCP) for 12 hours at $20^{\circ} \mathrm{C}$. After storage for 18 days in air at 13 ${ }^{\circ} \mathrm{C}$, at which time whole fruit firmness values averaged about $83 \mathrm{~N}$, half of the 1-MCP-treated fruit were treated with $100 \mu \mathrm{L} \cdot \mathrm{L}^{-1}$ ethylene for 12 hours and then transferred to $20^{\circ} \mathrm{C}$. 1-MCP delayed softening, and fruit treated with 1-MCP retained more green color than air-treated fruit when full ripe (firmness 10 to $15 \mathrm{~N}$ ). 1-MCP affected the activities of pectinmethylesterase (EC 3.2.1.11), $\alpha$ - (EC 3.2.1.22) and $\beta$-galactosidases (EC 3.2.1.23), and endo- $\beta$-1,4-glucanase (EC 3.2.1.4). The appearance of polygalacturonase (EC 3.2.1.15) activity was completely suppressed in 1-MCP-treated fruit for up to 24 days, at which time the firmness of 1-MCP-treated fruit had declined nearly $80 \%$ compared with initial values. The effect of exogenous ethylene applied to partially ripened 1-MCP-treated fruit differed for different ripening parameters. Ethylene applied to mid-ripe avocado exerted no effect on the on-going rate or final extent of softening of 1-MCP-treated fruit, even though polygalacturonase and endo-1,4- $\beta$-glucanase activities increased in response to ethylene. $\beta$-galactosidase decreased in 1-MCP-treated fruit in response to ethylene treatment. 1-MCP delayed the increase in solubility and depolymerization of water- and CDTA (1,2-cyclohexylenedinitrilotetraacetic acid)-soluble polyuronides, likely due to reduced polygalacturonase activity. At the full-ripe stage, the levels of arabinose, galactose, glucose, mannose, rhamnose, and xylose associated with the CDTA-soluble polyuronide fraction were similar among all treatments. In contrast, the galactose levels of water-soluble polyuronides declined $40 \%$ and $17 \%$ in control and 1-MCP treated fruit, respectively. Hemicellulose neutral sugar composition was unaffected by 1-MCP or ethylene treatment. The data indicate that the capacity of avocado fruit to recover from 1-MCP-mediated suppression of ripening can be only partially amended through short-term ethylene application and differs significantly for different ripening parameters.
\end{abstract}

The onset of ripening in avocado fruit is marked by a variety of biochemical changes including increases in ethylene production and respiration, softening, and development of flavor components (Seymour and Tucker, 1993). Fruit softening is a major aspect of the ripening process in many fruits and is considered to be a consequence of cell wall modifications. The cell walls of fleshy fruits have long been of interest since alterations in cell wall composition and structure are closely associated with changes in fruit firmness. Such organizational changes are an integral part of endogenously controlled ripening.

Ethylene plays an important role in the development of climacteric fruits, and whether applied exogenously or produced naturally, initiates and coordinates the ripening process. The importance of ethylene in regulating ripening has been demonstrated from studies involving molecular silencing (or "suppression") of ethylene biosynthetic enzymes (Picton et al., 1993; Theologis et al., 1993), receptor proteins (Klee and Tieman, 2002), and chemically suppressed ethylene perception (Sisler and Serek,

Received for publication 25 Nov. 2003. Accepted for publication 14 Apr. 2004 Journal Series No. R-09534 of the Florida Agricultural Experiment Station. This research supported, in part, by contributions from Rohm and Haas's AgroFresh Division and by a grant from the USDA Program in Tropical Agricultural Research (T-STAR).

1To whom reprint requests should be addressed. E-mail: djh@mail.ifas.ufl.edu
1997). These approaches have enabled detailed analysis of the relationship between ethylene and fruit ripening.

Ethylene antagonists, including 1-methylcyclopropene (1$\mathrm{MCP}$ ), a synthetic cyclopropene that binds ethylene receptors in an apparently noncompetitive fashion (Sisler and Serek, 1997; Yueming and Jiarui, 2000), have been particularly useful for attenuating ethylene effects in plant tissues (Sisler and Serek, 1997; Blankenship and Dole, 2003). In a previous study (Jeong et al., 2002), 1-MCP treatment of pre-climacteric 'Simmonds' avocado significantly prolonged the time required for softening and delayed the onset of the ethylene and respiratory climacterics. Similar effects of 1-MCP at attenuating softening have also been observed for 'Hass' (Feng et al., 2000), and 'Tower II' and 'Booth 7' (Jeong et al., 2003) avocado fruits. In our studies (Jeong et al., 2002, 2003), the softening of 1-MCP-treated pre-ripe avocado occurred unabated in the short-term following treatment with the ethylene antagonist, but rates of softening between 1-MCP-treated and control fruit diverged significantly and remained throughout the completion of ripening. These observations are consistent with the report of Hoeberichts et al. (2002), who demonstrated that the antagonistic effects of 1-MCP on ethylene responses in tomato fruit were evident at the levels of gene expression and on the overall physiology even when applied at advanced stages of ripening 
The purpose of the present study was to determine whether the persistent effects of 1-MCP in suppressing avocado ripening could be circumvented with an intervening exposure to ethylene upon fruit attaining a mid-ripe stage of development, defined herein on the basis of firmness values. The issue of 'ethylene rescue' of 1-MCP-treated fruit is of increasing interest as research into the use of 1-MCP is extended to crops that historically have required ethylene applications to ensure timely and uniform ripening.

\section{Materials and Methods}

Plant material. Mature avocado (Persea americana Mill. 'Booth 7') fruit were obtained from a commercial grower in Homestead, Fla., packed in fiberboard cartons, and transported to the Postharvest Horticulture Laboratory in Gainesville within $24 \mathrm{~h}$ of harvest. A total of 180 fruit were selected for uniformity of weight $(447 \pm 37 \mathrm{~g})$ and shape (diameter at equatorial region, $9.1 \pm 0.2 \mathrm{~cm}$ ), and then were surface sterilized in $90 \mathrm{~mm} \mathrm{NaOCl}$, rinsed in tap water, and dried.

1-MCP TREATMent. Twelve fruit were placed in 18-L containers (total 10 containers) and exposed to 1 -MCP by releasing the gas from a commercial powdered formulation (SmartFresh; Agro-Fresh, a division of Rohm and Hass Co., Philadelphia). The concentration selected, $0.9 \mu \mathrm{L} \cdot \mathrm{L}^{-1}$, was achieved through addition of $10 \mathrm{mg}$ of powder $(0.14 \%$ formulation $)$ to $100 \mathrm{~mL}$ of tap water following manufacturer's instructions. 1-MCP treatments were performed for $12 \mathrm{~h}$ at $20{ }^{\circ} \mathrm{C}$ and $85 \%$ relative humidity $(\mathrm{RH})$. 1 -MCP concentrations in the containers were measured using a gas chromatograph (GC) (Hewlett Packard 5890 II GC; Avondale, Pa.) equipped with a 80-100 mesh Chromosorb PAW stainless steel column (1.8 m × $3.18 \mathrm{~mm}$ i.d.; Supelco, Bellefonte, Pa.). Injector, oven, and detector (FID) were set at 150, 70 and 200 ${ }^{\circ} \mathrm{C}$, respectively. Isobutylene, which has a FID response similar to that of 1-MCP (Jiang et al., 1999), was used as a standard. Control fruit were maintained in identical containers without 1-MCP. Concentrations of $\mathrm{CO}_{2}$ in the treatment containers were monitored by gas chromatography (GC) and found to remain below $0.5 \%$ in all cases. Immediately following $1-\mathrm{MCP}$ treatment, fruit were removed from the chambers and transferred to $13{ }^{\circ} \mathrm{C}$ $(85 \% \mathrm{RH})$ storage facilities. After $18 \mathrm{~d}$ at $13{ }^{\circ} \mathrm{C}, 1-\mathrm{MCP}$-treated fruit were transferred to $20{ }^{\circ} \mathrm{C}$. Half of the 1-MCP-treated fruit were treated with $\mathrm{C}_{2} \mathrm{H}_{4}\left(100 \mu \mathrm{L} \cdot \mathrm{L}^{-1}\right)$ for $12 \mathrm{~h}$ at $20^{\circ} \mathrm{C}$ and then maintained at $20^{\circ} \mathrm{C}$ until full ripe. Control fruit (not exposed to 1-MCP) were stored for $12 \mathrm{~d}$ at $13{ }^{\circ} \mathrm{C}$ and then transferred to 20 ${ }^{\circ} \mathrm{C}$. The time of transfer for 1-MCP-treated (19 d) and control (12 d) fruit, hereafter referred to as "mid-ripe" fruit, from $13{ }^{\circ} \mathrm{C}$ to $20^{\circ} \mathrm{C}$ was based on fruit attaining firmness values (whole fruit compression) of 75 to $90 \mathrm{~N}$, representing about a $50 \%$ decline in firmness values compared with freshly harvested fruit. Samples of fruit from each treatment were evaluated for fruit quality at 2- to 3-d intervals until they reached the full-ripe stage (whole fruit firmness values of 10 to $20 \mathrm{~N}$ ). Mesocarp tissue derived from the equatorial region of 5 fruit, which were used to measure mesocarp firmness, was stored at $-30^{\circ} \mathrm{C}$ and used for analysis of cell wall enzymes and structural polysaccharides.

Fruit FIRMNESS. Firmness changes were measured using both whole fruit compression and puncture analysis of mesocarp tissue. For whole fruit compression analysis, 10 fruit were chosen from each treatment and measured repeatedly. For mesocarp puncture analysis, five fruit were selected from each treatment at every evaluation date. Whole fruit firmness was determined on unpeeled fruit using an Instron Universal Testing Instrument (model 4411, Canton, Mass.) fitted with a flat-plate probe $(5 \mathrm{~cm}$ in diameter) and $50 \mathrm{~kg}$ load cell. After establishing zero-force contact between the probe and the equatorial region of the fruit, the probe was driven with a crosshead speed of $10 \mathrm{~mm} \cdot \mathrm{min}^{-1}$. The force was recorded at $2.5 \mathrm{~mm}$ compression at two equidistant points on the equatorial region of each fruit. Mesocarp firmness was determined on pared fruit using the Instron Universal Testing Instrument fitted with a $10-\mathrm{mm}$-diameter convex probe and $50 \mathrm{~kg}$ load cell. After establishing zero-force contact between the probe and the mesocarp tissue, the probe was driven with a crosshead speed of $50 \mathrm{~mm} \cdot \mathrm{min}^{-1}$. The force recorded at $5 \mathrm{~mm}$ puncture depth was determined at two equidistant points on the equatorial region of each fruit. Ten fruit of each treatment were measured at 2 to $3 \mathrm{~d}$ intervals until they reached the full-ripe stage (10 to $20 \mathrm{~N}$ in the compression test; 5 to $10 \mathrm{~N}$ in the puncture test).

Preparation of Cell-free protein extract and enzyme ASSAYS. Cell-free protein extracts were prepared from avocado mesocarp as previously described (Jeong et al., 2002). Protein content was measured using the bicinchoninic method (Smith et al., 1985) with bovine serum albumin as a standard. Polygalacturonase (PG, E.C. 3.2.1.15) activity was assayed reductometrically using the method of Jeong et al. (2002). Uronic acid reducing groups were measured using the method of Milner and Avigad (1967). PG activity was expressed as molD-galacturonic acid equivalents produced per $\mathrm{kg}$ protein per minute. Pectinmethylesterase (PME, E.C. 3.1.1.11) was measured using modifications of the method of Hagerman and Austin (1986) and activity expressed as $\Delta \mathrm{A}_{620}$ per $\mathrm{mg}$ protein per minute. Endo- $\beta$-1,4-glucanase (EGase; E.C. 3.2.1.4) activity was measured viscometrically using the method of Jeong et al. (2002). Activity was expressed as \% change in flow per mg protein per min. Alpha- and $\beta$-galactosidase activities were measured using modifications of the method of Pharr et al. (1976). Activities were expressed as mol of $\mathrm{NO}_{2}$-phenol equivalents released per kilogram protein per minute.

Polyuronide AND HEMICELlulose EXTRACTION AND ANALYSIS. Ethanol-insoluble solids (EIS) and water- and CDTA- (1,2-cyclohexylenedinitrilotetraacetic acid) soluble polyuronide fractions were prepared as described (Jeong et al., 2002). Total uronic acids in the EIS preparations were determined using the method of Ahmed and Labavitch (1977). Uronic acid (UA) content in the water- and CDTA-soluble polyuronide fractions was determined by the hydroxydiphenyl assay (Blumenkrantz and Asboe-Hansen, 1973) and expressed as $\mu$ g galacturonic acid equivalents per mg EIS. Sepharose CL-2B-300 gel-permeation chromatography of water- and CDTA-soluble uronic acids was conducted as described in Huber and O'Donoghue (1993). The UA content in each column fraction was expressed as a percentage of the total UA recovered. Hemicelluloses were isolated and purified using DEAE-Sephadex chromatography as described in De Vetten and Huber (1990).

Compositional analysis of PeCtins AND HeMicelluloses. Neutral-sugar composition of water- and CDTA-soluble polyuronides and $4 \mathrm{~m}$ alkali-extractable hemicelluloses was analyzed by hydrolysis and alditol acetate derivatization (Albersheim et al., 1967). The alditol acetates were separated by gas chromatography (model 5890 II; Hewlett Packard, Atlanta, Ga.) using a HP-5 (crosslinked 5\% phenyl methyl siloxane) capillary column (Agilent Technologies, Wilmington, Del.; $25 \mathrm{~m} \times 0.200 \mathrm{~mm} \times$ $0.33 \mu \mathrm{m})$ and flame ionization detection. The oven was set at 210 ${ }^{\circ} \mathrm{C}$, and detector and injector were operated at $250{ }^{\circ} \mathrm{C}$.

STatistical Analysis. The experiments were conducted in a completely randomized design. Statistical procedures were per- 
formed using the PC-SAS software package (SAS Insititute, 1985). Data were subjected to analysis of variance using the General Linear Model (Minitab, State College, Pa.). Differences between means were determined using Duncan's multiple range test.

\section{Results}

Avocado softening. All experiments involved fruit stored initially at $13{ }^{\circ} \mathrm{C}$ followed by transfer to $20^{\circ} \mathrm{C}$. Fruit were transferred to $20^{\circ} \mathrm{C}$ when they attained a stage of mid-ripening, defined here as the time at which whole-fruit compression attained values within the range of 75 to $90 \mathrm{~N}$. These values represent a nearly $50 \%$ decline relative to fruit at the start of the experiment. The time of transfer averaged 12 and $18 \mathrm{~d}$, respectively, for the control and 1-MCP-treated fruit and the total storage duration (days at $13{ }^{\circ} \mathrm{C}$ plus days at $20^{\circ} \mathrm{C}$ ) averaged 16 and $28 \mathrm{~d}$ for control and 1-MCP-treated fruit.

Based on whole-fruit compression analysis, the rates of softening were comparable for fruit of all treatments over the initial $8 \mathrm{~d}$ of storage at $13^{\circ} \mathrm{C}$ (Fig. 1). Thereafter, softening trends for control and 1-MCP-treated fruit diverged significantly $(P<0.05)$. Control fruit required nearly $12 \mathrm{~d}$ at $13{ }^{\circ} \mathrm{C}$ to reach a mid-ripe stage (time of transfer to $20^{\circ} \mathrm{C}$ ) and reached a full-ripe condition following an additional $4 \mathrm{~d}$ at $20^{\circ} \mathrm{C}$ (Fig. 1A). In contrast, fruit treated with $0.9 \mu \mathrm{L} \cdot \mathrm{L}^{-1} 1-\mathrm{MCP}$ required about $18 \mathrm{~d}$ at $13{ }^{\circ} \mathrm{C}$ to reach a midripe stage, and an additional $10 \mathrm{~d}$ after transfer to $20^{\circ} \mathrm{C}$ to reach the full-ripe condition. The rate of softening of 1-MCP-treated fruit was relatively constant throughout the duration of storage, showing only a slight increase following transfer of fruit to 20 ${ }^{\circ} \mathrm{C}$. Treatment with $100 \mu \mathrm{L} \cdot \mathrm{L}^{-1}$ ethylene $\left(12 \mathrm{~h}\right.$ at $\left.20^{\circ} \mathrm{C}\right)$ upon reaching the mid-ripe stage did not affect the rate of softening of 1-MCP-treated fruit. Final firmness (whole fruit compression) of the 1-MCP-treated fruit with or without an intervening ethylene exposure averaged 13.1 and $12.5 \mathrm{~N}$, respectively.

Firmness determined via mesocarp puncture analysis showed similar patterns in both control and 1-MCP-treated fruit during early storage, diverged significantly $(P<0.05)$ after about $8 \mathrm{~d}$ and, in 1-MCP-treated fruit, was unaffected by an intervening exposure to ethylene (Fig. 1B). In all cases, 1-MCP-treated fruit eventually softened to values similar to those of control fruit.

ACTIVITIES OF CELL WALL HYDROLASES IN RESPONSE TO 1-MCP AND ETHYLENE. The activities of cell wall hydrolases in avocado fruit in response to 1-MCP and application of ethylene are shown in FigS. 2 and 3. In control fruit, polygalacturonase (PG) activity was initially low and increased only slightly throughout the attainment of a mid-ripe stage. After transfer to $20^{\circ} \mathrm{C}, \mathrm{PG}$ activity increased about 9.6-fold over the subsequent $4 \mathrm{~d}$ of storage (Fig. 2A). PG activity in 1-MCP-treated fruit remained unchanged upon reaching a mid-ripe stage after $18 \mathrm{~d}$ at $13{ }^{\circ} \mathrm{C}$. PG activity in 1-MCP-treated fruit remained low up to $6 \mathrm{~d}$ after transfer to $20{ }^{\circ} \mathrm{C}$, thereafter increasing 3.9-fold at the time of full-ripeness (Fig. 2A) and coinciding with peak climacteric ethylene production (ethylene data not shown). Ethylene application to 1-MCPtreated fruit did not increase the timing of PG accumulation but resulted in levels nearly 9.2-fold higher than values at the start of the experiment. This increase represented $\approx 2.5$-fold higher levels compared with those in 1-MCP-treated fruit without an intervening ethylene exposure.

Trends for pectinmethylesterase (PME) activity were similar for all treatments, yet the characteristic decline noted during avocado ripening (Awad and Young, 1980) was significantly delayed in 1-MCP-treated fruit (Fig. 2B). The levels of PME in

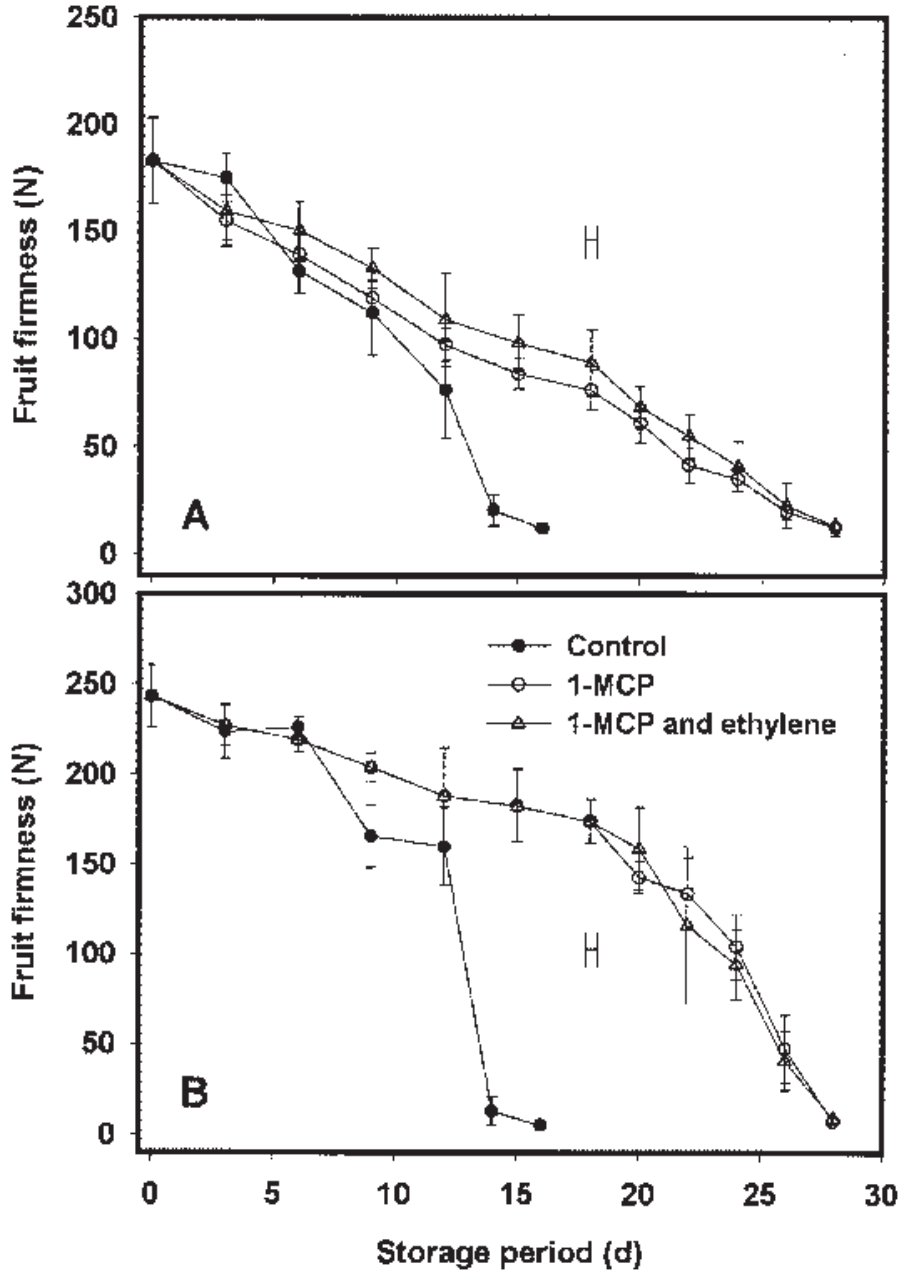

Fig. 1. Fruit firmness (N) of 'Booth 7' avocados treated with 1-methylcyclopropene (1-MCP, $0.9 \mu \mathrm{L} \cdot \mathrm{L}^{-1}$ for $12 \mathrm{~h}$ at $20^{\circ} \mathrm{C}$ ). After treatment, fruit were stored at 13 ${ }^{\circ} \mathrm{C}$ until firmness values reached 75 to $90 \mathrm{~N}$ (whole fruit compression) or 160 to $175 \mathrm{~N}$ (mesocarp puncture). Control and 1-MCP-treated fruit reached firmness values in these ranges after $12 \mathrm{~d}$ and $18 \mathrm{~d}$, respectively, at which time all fruit were transferred to $20^{\circ} \mathrm{C}$. At the time of transfer, half of the 1-MCP-treated fruit were exposed to ethylene $\left(100 \mu \mathrm{L} \cdot \mathrm{L}^{-1}\right.$ for $12 \mathrm{~h}$ at $\left.20^{\circ} \mathrm{C}\right)$. Vertical bars represent standard deviation of 10 independent samples for whole fruit compression tests (A) or five independent samples for puncture tests (B). Horizontal bars represent the time interval of ethylene treatment $\left(100 \mu \mathrm{L} \cdot \mathrm{L}^{-1}\right.$ for $12 \mathrm{~h}$ at $\left.20^{\circ} \mathrm{C}\right)$.

1-MCP-treated fruit after $28 \mathrm{~d}$ were similar to those noted for control fruit after $16 \mathrm{~d}$ but, unlike the trends for PG activity, were unaffected by the intervening ethylene exposure.

Endo- $\beta$-1,4-glucanase (EGase) activity was first detected in control fruit at day 6 , increasing a further 3.7 -fold during storage at $13{ }^{\circ} \mathrm{C}$. Upon reaching a mid-ripe condition (based on firmness values) and subsequent transfer to $20^{\circ} \mathrm{C}$, EGase activity increased 4.7-fold compared with activity present at the time of transfer (Fig. 3A). Increases in EGase were significantly delayed and suppressed in 1-MCP-treated fruit, with activity first detected at the full ripe condition (day 28) and representing about $45 \%$ of levels in control fruit at similar firmness values (day 16). Ethylene treatment of 1-MCP-treated fruit significantly advanced the timing of EGase accumulation (Fig. 3A). Activity was first detected at day 24 ( $4 \mathrm{~d}$ after ethylene treatment) and by day 28 had increased to about $83 \%$ of the maximum levels in control fruit and $\approx 1.8$-fold higher than the values noted for 1 -MCP-treated fruit without ethylene exposure.

Alpha- and $\beta$-galactosidase activities (Fig. 3B-C) decreased 

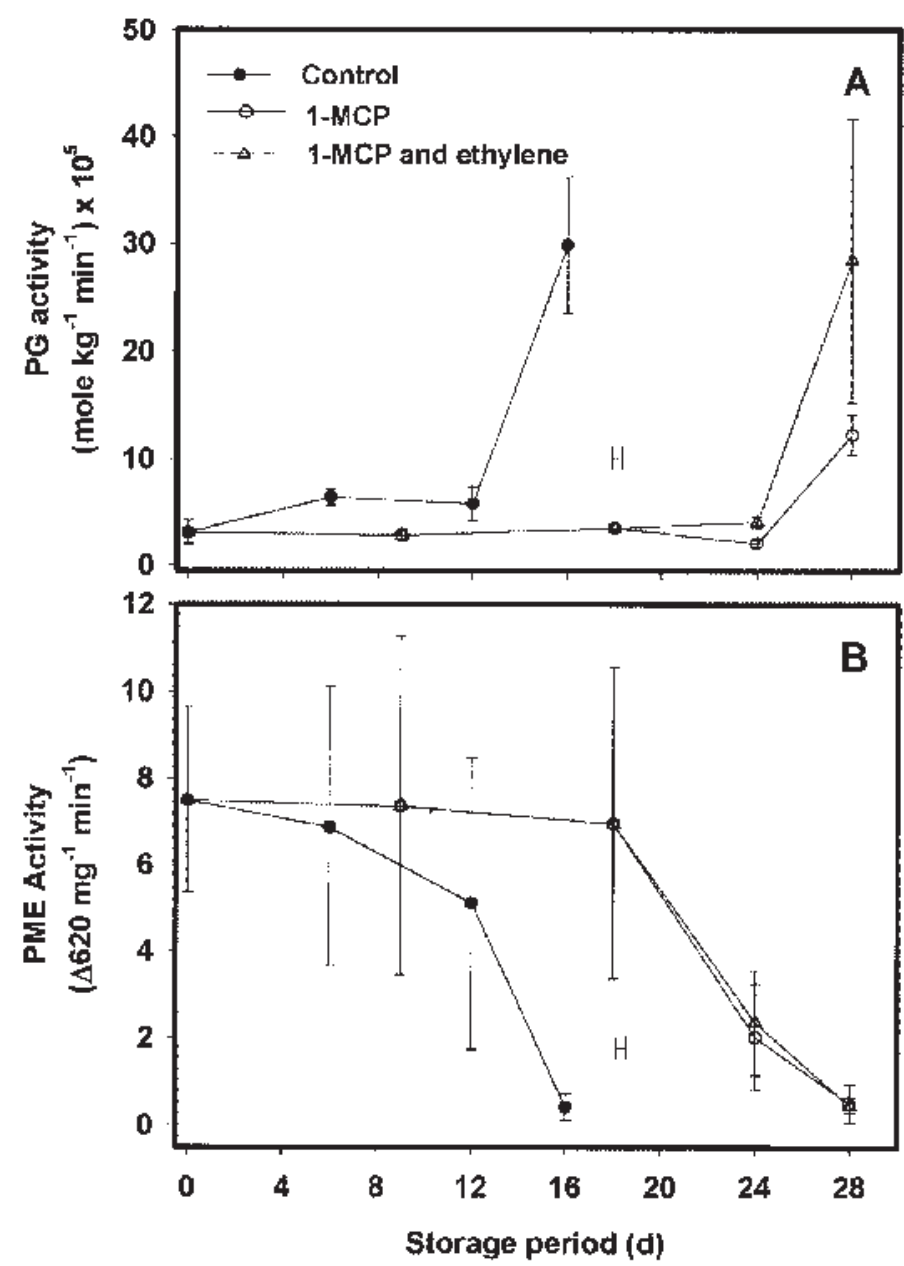

Fig. 2. Polygalacturonase (PG) and pectinmethylesterase (PME) activities of avocados treated with 1-methylcyclopropene (1-MCP, $0.9 \mu \mathrm{L} \cdot \mathrm{L}^{-1}$ for $12 \mathrm{~h}$ at $\left.20{ }^{\circ} \mathrm{C}\right)$. Details are as described for Fig. 1. Vertical bars represent standard deviation of five independent samples. Horizontal bars represent the time interval of ethylene treatment $\left(100 \mu \mathrm{L} \cdot \mathrm{L}^{-1}\right.$ for $12 \mathrm{~h}$ at $\left.20^{\circ} \mathrm{C}\right)$.

slightly ( $\beta$-gal) or remained constant $(\beta$-gal) through $12 \mathrm{~d}$ of storage followed by significant declines coincident with the ethylene climacteric (ethylene data not shown) and attainment of the full-ripe stage. The ripening-associated decline in activities was delayed in 1-MCP-treated fruit, and either slightly ( $\beta$-gal) or significantly $(\beta-\mathrm{gal})$ promoted in response to exogenous ethylene (Fig. 3B-C).

SOlubility AND MOLECUlar mass OF POLYURONIDES. The solubilility of cell wall pectic fractions was markedly altered during ripening and in response to 1-MCP (Fig. 4). Increased recoveries of water-soluble polyuronides (WSP) were first evident in control fruit after $6 \mathrm{~d}$ at $13{ }^{\circ} \mathrm{C}$ (Fig. 4A), reaching nearly 120 $\mathrm{g} \cdot \mathrm{kg}^{-1} \mathrm{UA}$ equivalents EIS at the full-ripe stage (day 16). Levels of WSP in 1-MCP-treated fruit remained unchanged throughout the attainment of a mid-ripe stage. After transfer to $20^{\circ} \mathrm{C}$, levels of WSP in 1-MCP-treated fruit increased and, upon reaching the full-ripe stage (day 28), reached values comparable to or slightly higher than those for ripe controls. Ethylene treatment had negligible influence on the levels of WSP in 1-MCP-treated fruit (Fig. 4A).

The patterns of solubility changes in CDTA-soluble polyuronides (CSP) were inversely related to those for WSP, with declines in CSP noted at 12 and $24 \mathrm{~d}$ for control and 1-MCPtreated fruit, respectively (Fig. 4B). Although the decline in CSP
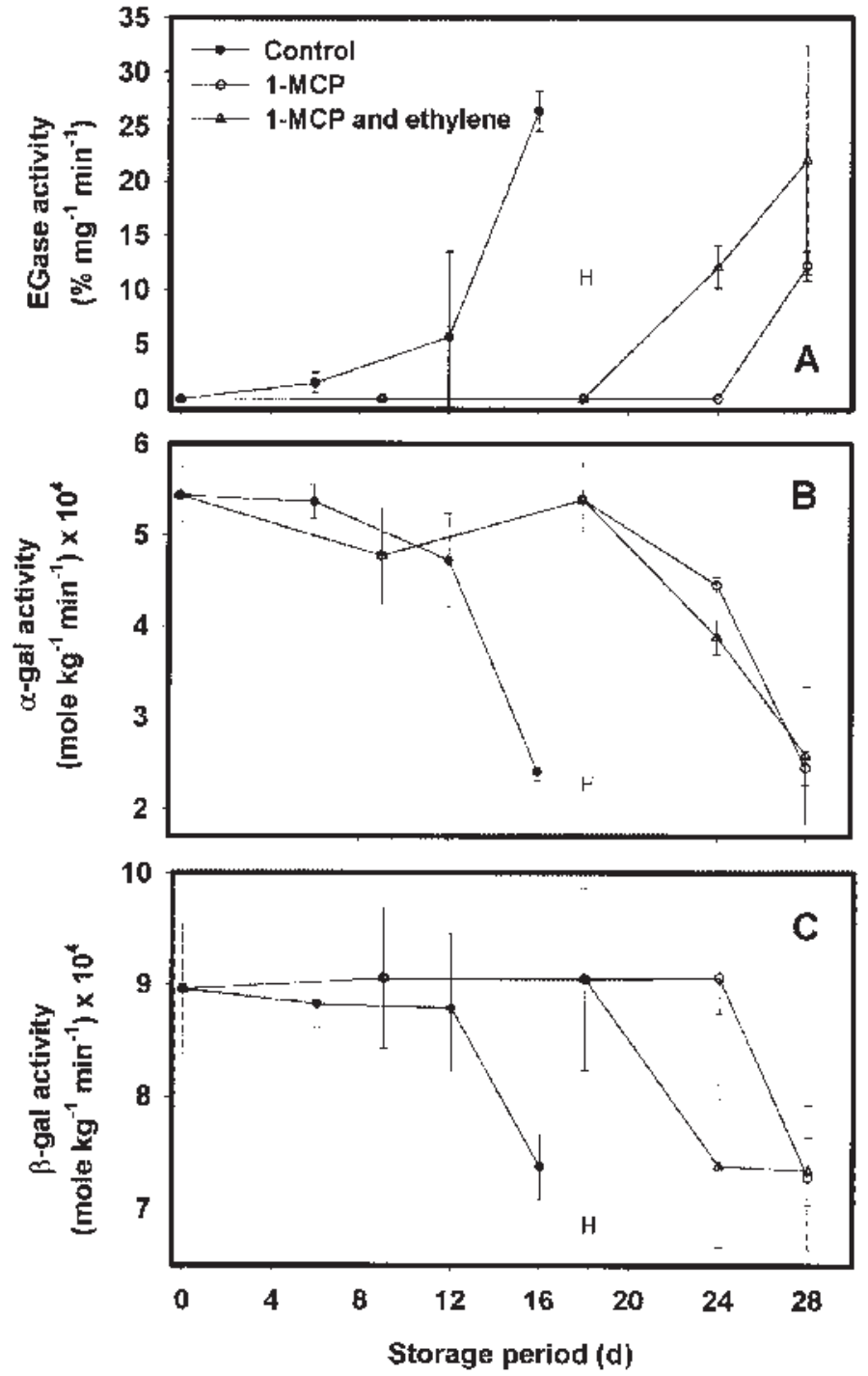

Fig. 3. Endo- $\beta$-1,4-glucanase (EGase) and $\alpha$-, $\beta$-galactosidase $(\alpha$-, $\beta$-gal) activity of avocados treated with 1-methylcyclopropene (1-MCP, $0.9 \mu \mathrm{L} \cdot \mathrm{L}^{-1}$ for $12 \mathrm{~h}$ at $20{ }^{\circ} \mathrm{C}$ ). Details are as described for Fig. 1. Vertical bars represent standard deviation of five independent samples. Horizontal bars represent the time interval of ethylene treatment $\left(100 \mu \mathrm{L} \cdot \mathrm{L}^{-1}\right.$ for $12 \mathrm{~h}$ at $\left.20{ }^{\circ} \mathrm{C}\right)$.

during ripening was highly significant, $25 \%$ and $5 \%$ to $10 \%$ for control and 1-MCP-treated fruit, respectively, the levels of CSP were much lower than WSP throughout ripening. CSP constituted $\approx 6.8 \%$ (control), $8.3 \%$ (1-MCP treated), and 7.8\% (1-MCP and exogenous ethylene treated) of total EIS UA levels at the full-ripe $(10$ to $20 \mathrm{~N})$ stage. Ethylene treatment did not significantly affect CSP levels of the 1-MCP-treated fruit.

Water-soluble polyuronides from pre-ripe fruit (day 0), representing $\approx 33 \%$ (69.2 $\mathrm{g} \cdot \mathrm{kg}^{-1}$ galacturonic acid equiv.) of total UA levels $\left(209.3 \mathrm{~g} \cdot \mathrm{kg}^{-1}\right)$ in EIS, eluted as a symmetrical, polydisperse population with a notable absence of excluded, high mol mass polymers. As ripening proceeded (day 6 through 16; Fig. 5A) in control fruit, the mol mass of WSP declined sharply, coinciding with increased recoveries of this pectin fraction. Mol mass downshifts of WSP were significantly delayed in 1-MCP-treated fruit (Fig. 5B). WSP from 1-MCP-treated fruit at the full-ripe stage (day 28) were of slightly higher mol mass (elution peak $=56 \mathrm{~mL}$ ) than those from control fruit (elution peak $=58 \mathrm{~mL}$ ). Although 1-MCP-treated fruit required nearly 12 additional days 


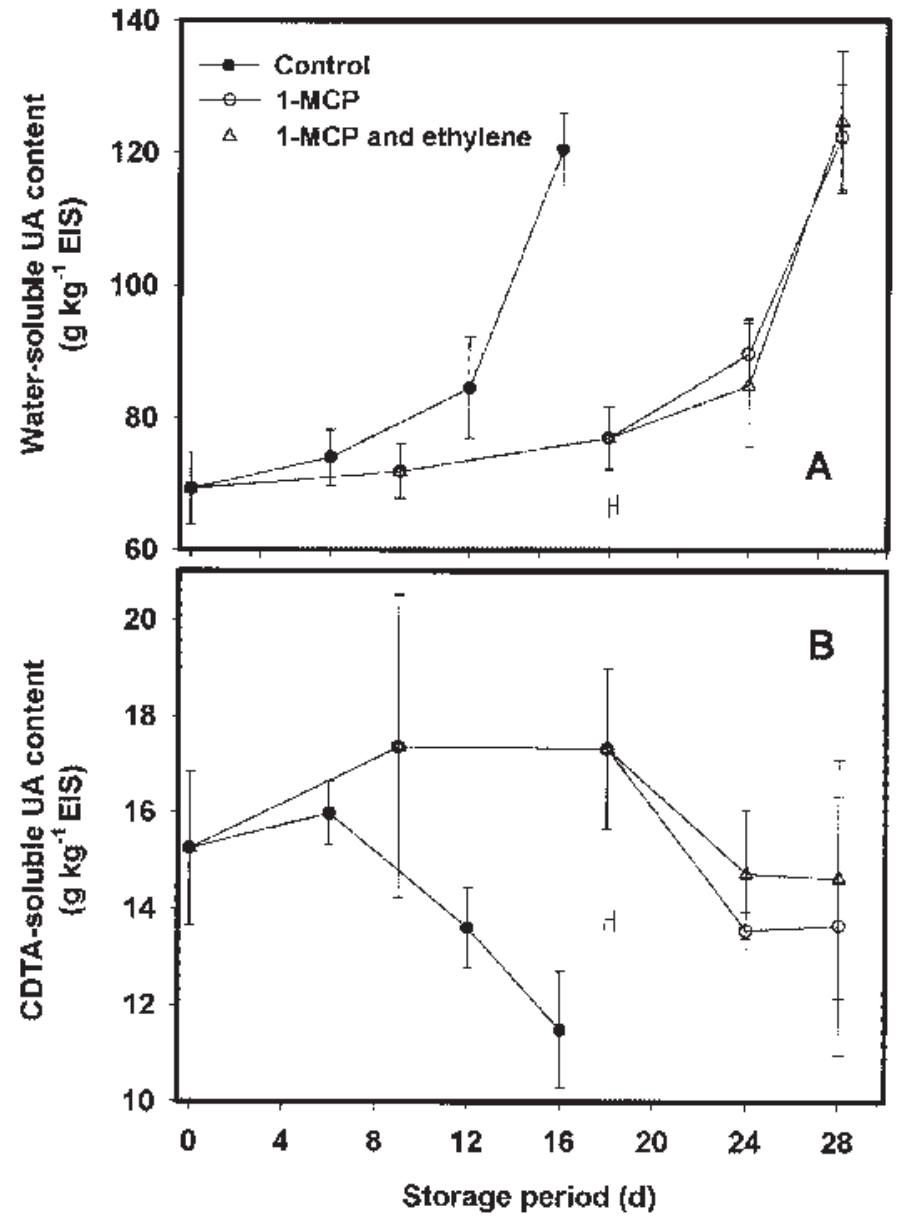

Fig. 4. The changes in water- and CDTA- (1,2-cyclohexylenedinitrilotetraacetic acid) soluble uronic acids (UA) in ethanol-insoluble solids (EIS) from avocados treated with 1-methylcyclopropene (1-MCP, $0.9 \mu \mathrm{L} \cdot \mathrm{L}^{-1}$ for $12 \mathrm{~h}$ at $\left.20^{\circ} \mathrm{C}\right)$. Details are as described for Fig. 1. Vertical bars represent standard deviation of five independent samples. Horizontal bars represent the time interval of ethylene treatment $\left(100 \mu \mathrm{L} \cdot \mathrm{L}^{-1}\right.$ for $12 \mathrm{~h}$ at $\left.20{ }^{\circ} \mathrm{C}\right)$.

to reach a full-ripe stage, the levels of WSP in 1-MCP-treated and control fruit at comparable firmness values (10 to $20 \mathrm{~N}$ ) represented a proportionally similar percentage $(70 \%)$ of total EIS UA. Ethylene treatment of mid-ripe, 1-MCP-treated fruit slightly but consistently promoted the downshift in mol mass of WSP within $6 \mathrm{~d}$ of exposure (after $24 \mathrm{~d}$ of storage), but ethyleneinduced differences were negligible by $28 \mathrm{~d}$ of storage (compare Figs. 5B-C). Mol mass changes in CSP (Fig. 6) paralleled those for WSP; however, the influence of ethylene at promoting the downshift in mol mass of these polymers was more pronounced than for WSP (compare Figs. 5C and 6C, day 24).

NeUTRAL SUGAR COMPOSITION OF AVOCADO POLYURONIDES AND HEMICELLULOSES. Neutral sugar composition of WSP changed significantly during ripening of control fruit (Table 1). The major neutral sugars included arabinose, galactose, and xylose, collectively comprising 73 and $83 \%$ (mol ratio) of the total neutral sugars in WSP of fruit at harvest and at the full-ripe stage, respectively. During storage, significant $(P<0.05)$ proportional declines occurred in xylose $(60 \%)$, mannose $(72 \%)$, glucose $(31 \%)$, and galactose $(41 \%)$, whereas arabinose increased $(129 \%)$. The largest change in sugar levels occurred after transfer of fruit to $20^{\circ} \mathrm{C}$ and coincident with the period of climacteric ethylene production (days 12-14, ethylene data not shown).

Arabinose, xylose, and galactose also comprised the major

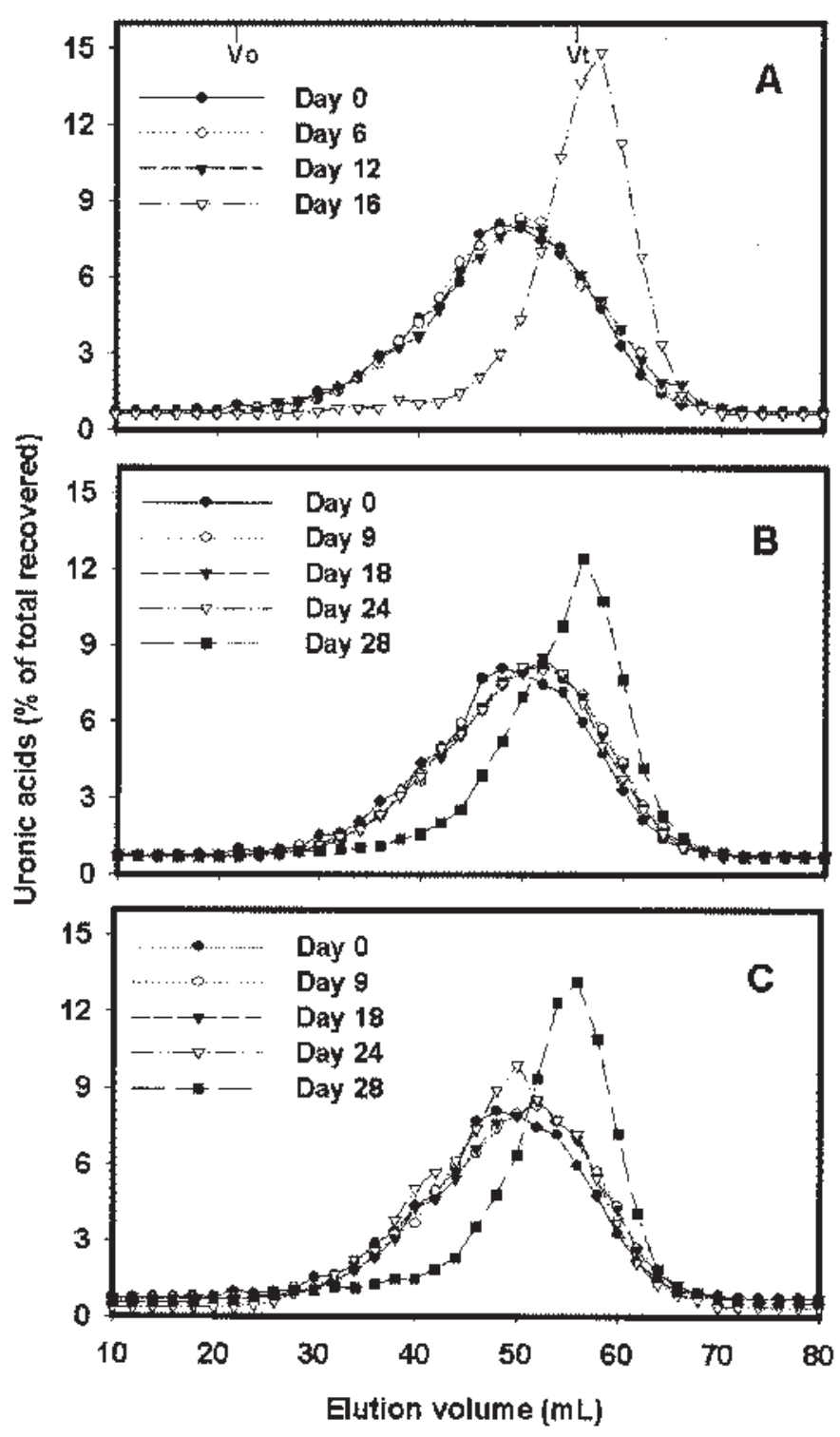

Fig. 5. Sepharose CL-2B-300 gel filtration profiles of water-soluble polyuronides from avocado fruit. Water-soluble polyuronides $(\approx 0.5 \mathrm{mg}$ galacturonic acids equivalents in $2 \mathrm{~mL}$ ) derived from avocado ethanol-insoluble solids were applied to the Sepharose column and individual fractions were measured for uronic acids content. Data for each fraction expressed as a percentage of the total eluted uronic acids. Tick marks at the top of the figure indicate $\mathrm{V}_{\mathrm{O}}$, Void volume (left); $\mathrm{V}_{\mathrm{t}}$, total volume (right). (A) Polyuronides from control fruit; (B) 1-MCP-treated fruit; (C) 1-MCP-treated fruit exposed to ethylene.

neutral sugars in WSP from 1-MCP-treated fruit, collectively comprising $84 \%$ of the neutral sugars in this pectin fraction at the full-ripe stage (Table 2). 1-MCPdelayed the proportional increases in arabinose and decreases in xylose and mannose but had less influence on the magnitude of these changes. By the full-ripe stage, at comparable firmness values, the proportional levels of arabinose in 1-MCP-treated fruit had increased $106 \%$, whereas xylose and mannose declined $58 \%$ and $65 \%$, respectively. In comparison, proportional levels of arabinose increased $129 \%$ and xylose and mannose declined $60 \%$ and $72 \%$, respectively, in control fruit. The changes in the levels of these sugars were not significantly influenced by ethylene treatment (Table 2). In sharp contrast to arabinose, xylose, and mannose, the levels of WSP-associated galactose were persistent in 1-MCP-treated fruit, declining only 


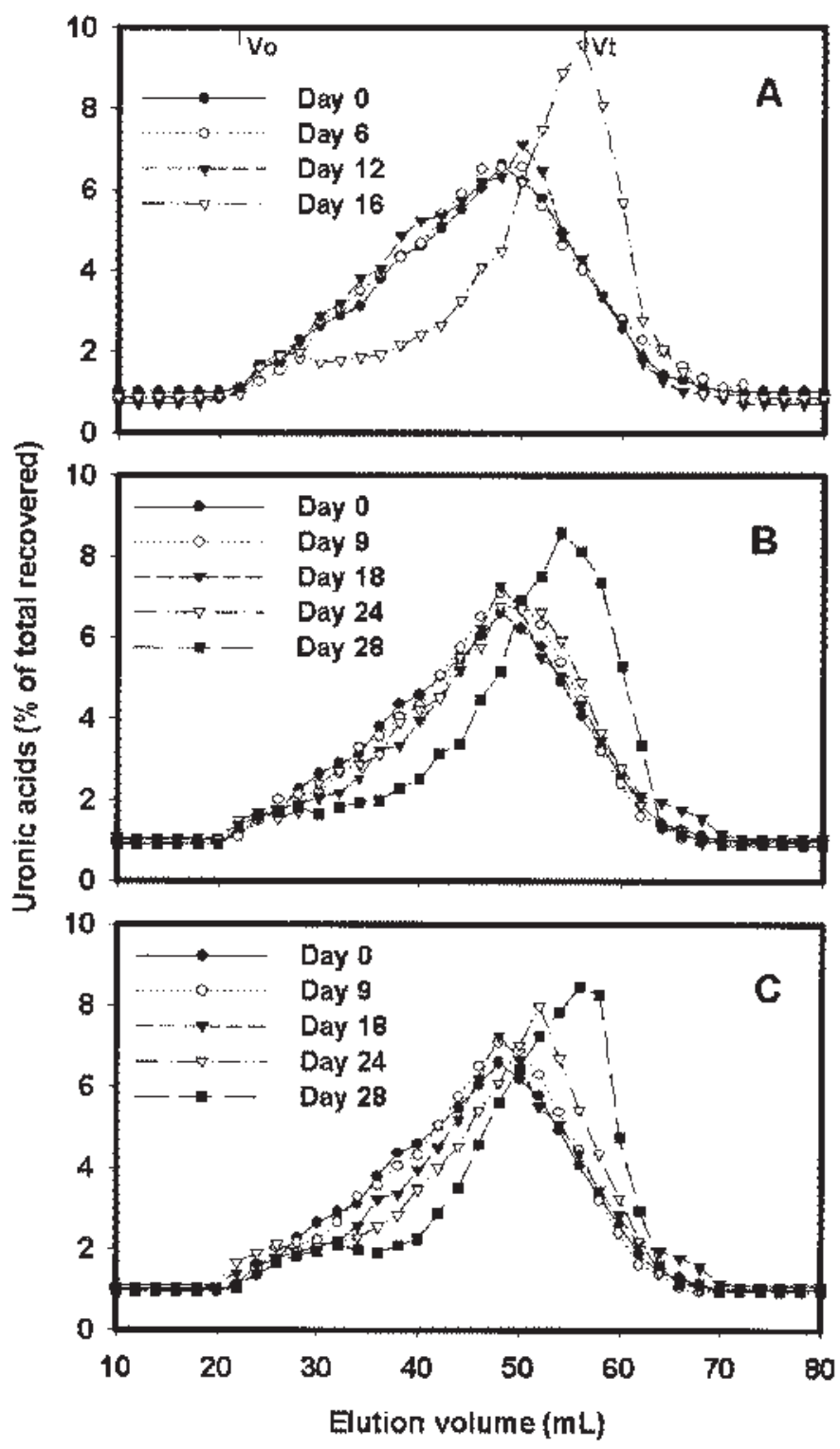

Fig. 6. Sepharose CL-2B-300 gel filtration profiles of CDTA-soluble polyuronides from avocado fruit. CDTA-soluble polyuronides $(\approx 0.5 \mathrm{mg}$ galacturonic acids equivalents in $2 \mathrm{~mL}$ ) derived from avocado ethanol-insoluble solids were applied to the Sepharose column and individual fractions were measured for uronic acids content. Data for each fraction expressed as a percentage of the total eluted uronic acids. Tick marks at the top of the figure indicate $\mathrm{V}_{\mathrm{O}}$, Void volume (left); $\mathrm{Vt}_{\mathrm{t}}$, total volume (right). (A) Polyuronides from control fruit; (B) 1-MCP-treated fruit; (C) 1-MCP-treated fruit exposed to ethylene.

$17 \%$ during ripening and softening compared with a $41 \%$ decline in control fruit. Ethylene treatment of 1-MCP-treated fruit did not influence galactose levels (Table 2). The proportional composition and changes in neutral sugars in CSP (data not shown), a relatively nonabundant pectic fraction in avocado fruit (Fig. 4), during ripening were similar to those for the WSP.

The neutral sugar composition of avocado fruit hemicelluloses at the time of initial storage (day 0) included arabinose (11\%), xylose $(35 \%)$, mannose $(11 \%)$, glucose $(25 \%)$, and galactose $(15 \%)$. Other than proportional declines in mannose (control, 17\%; 1-MCP-treated, 43\%; 1-MCP + ethylene-treated, 33\%), neutral sugar composition of hemicelluloses changed negligibly as fruit reached a full-ripe condition.

\section{Discussion}

The patterns of ripening and softening of 'Booth 7' avocado fruit in response to 1-MCP were similar to those exhibited by the cv. Simmonds (Jeong et al., 2002). Softening was significantly delayed in response to 1-MCP treatment, consistent with the role of ethylene in softening-related metabolism in ripening fruits (Lelievre et al., 1997; Saltveit, 1999). Similar effects of 1-MCP at attenuating softening have been observed for 'Hass' (Feng et al., 2000), and 'Tower II' and 'Booth 7' (Jeong et al., 2003) avocado fruits, apricot (Prunus armeniaca L.) (Fan et al., 2000), and 'McIntosh' and 'Delicious' apple (Malus $\times$ domestica Borkh.) (Rupasinghe et al., 2000) fruits.

The ripening of avocado was accompanied by significant changes in the levels of cell wall enzymes. As reported in previous studies, significant increases in PG and EGase activities (Awad and Young, 1979; Christofferson et al., 1984) and a decline in PME activities (Awad and Young, 1980; Zauberman and Schiffmann-Nadel, 1972) were noted. Consistent with studies of 'Simmonds' avocado (Jeong et al., 2002), PG activity in 'Booth 7 ' was strongly suppressed in 1-MCP-treated fruit, showing little accumulation over basal levels during $24 \mathrm{~d}$ of storage. In spite of the strong and persistent suppression of PG activity, 1-MCPtreated fruit ultimately softened to values comparable to yet consistently higher than those of control fruit, indicating that the main phase of avocado softening does not require increased PG activity. This observation is consistent with reports for the role of this enzyme in tomato (Lycopersicon esculentum Mill.), wherein softening of PG-antisense transformants was largely unaffected until the late stages of ripening (Carrington et al., 1993; Kramer et al., 1992). Application of ethylene to 1-MCP-treated fruit did not influence the timing of PG accumulation but significantly enhanced activity levels compared with fruit treated with only 1-MCP. The accumulation of PG in response to ethylene-action antagonists (1-MCP) and to ethylene treatment is consistent with the ethylene-responsiveness of PG activity and transcript abundance demonstrated for tomato fruit (Lincoln et al., 1987; Zheng et al., 1994). In contrast to the nearly complete suppression of PG activity by $1-\mathrm{MCP}$, the activities of PME, $\alpha$-and $\beta$-gal, and EGase in avocado were delayed but essentially followed patterns of accumulation or decline that paralleled those of control fruit.

The mol mass downshifts of WSP and CSP during ripening of 'Booth 7' avocado fruit were extensive and similar to those reported for the cultivars Lula (Huber and O'Donoghue, 1993), Simmonds (Jeong et al., 2002), and Hass (Sakurai and Nevins, 1997). Both pectin solubility and depolymerization were significantly delayed in 1-MCP-treated 'Booth 7' avocado fruit. The major downshifts in mol mass of WSP and CSP in 1-MCP-treated fruit were noted at day 28 (Figs. 5B-C and 6B-C), at which time increased PG activity was first evident in 1-MCP-treated fruit. The PG-mediated depolymerization of pectins in ripening avocado greatly exceeds that noted for tomato and other fruits (Huber et al., 2001) and has an obligatory requirement for methyl de-esterification (Wakabayashi, 2000; Wakabayashi et al., 2003). PME activity, however, remained high in 1-MCP-treated fruit and was likely not a limiting factor in the delayed depolymerization of WSP and CSP.

Of the other cell wall enzymes ( $\alpha$-gal, $\beta$-gal, EGase) measured in avocado fruit, all were affected by 1-MCP treatment and in parallel with the general inhibition of ripening. Application of ethylene to 1-MCP-treated fruit stimulated a rapid and significant increase in EGase activity and an earlier decline in $\beta$-gal activity compared with fruit treated with 1-MCPalone. The effect of 1-MCP 
Table 1. Neutral sugar composition of water-soluble uronic acids from ethanol-insoluble solids prepared from avocado stored at $13{ }^{\circ} \mathrm{C}$ for $12 \mathrm{~d}$ and then transferred to $20^{\circ} \mathrm{C}$. Values followed by the same letter in a column do not differ significantly according to Duncan's multiple range test $(P<0.05)$.

\begin{tabular}{|c|c|c|c|c|c|c|c|}
\hline \multirow[b]{2}{*}{ Stage } & \multicolumn{6}{|c|}{ Neutral sugar composition $(\text { mole } \%)^{z}$} & \multirow{2}{*}{$\begin{array}{c}\mathrm{NS} / \mathrm{UA} \\
(\mathrm{mol} \text { ratio)y }\end{array}$} \\
\hline & Rha & Ara & Xyl & Man & Glu & Gal & \\
\hline Before storage & $9.8 \mathrm{a}$ & $26.0 \mathrm{~b}$ & $21.9 \mathrm{a}$ & $10.7 \mathrm{a}$ & $6.5 \mathrm{a}$ & $25.1 \mathrm{a}$ & 0.41 \\
\hline $6 \mathrm{~d}$ at $13{ }^{\circ} \mathrm{C}$ & $9.5 \mathrm{a}$ & $26.6 \mathrm{~b}$ & $25.6 \mathrm{a}$ & $9.2 \mathrm{a}$ & $7.8 \mathrm{a}$ & $21.3 \mathrm{a}$ & 0.48 \\
\hline $12 \mathrm{~d}$ at $13{ }^{\circ} \mathrm{C}$ & $11.4 \mathrm{a}$ & $23.4 \mathrm{~b}$ & $22.5 \mathrm{a}$ & $10.4 \mathrm{a}$ & $9.1 \mathrm{a}$ & $23.3 \mathrm{a}$ & 0.48 \\
\hline $12 \mathrm{~d}$ at $13{ }^{\circ} \mathrm{C}$ & & & & & & & \\
\hline$+4 \mathrm{~d}$ at $20{ }^{\circ} \mathrm{C}$ & $9.3 \mathrm{a}$ & 59.6 a & $8.7 \mathrm{~b}$ & $3.0 \mathrm{~b}$ & $4.5 \mathrm{a}$ & $14.9 \mathrm{~b}$ & 0.97 \\
\hline
\end{tabular}

${ }^{2}$ Rha $=$ rhamnose $;$ Ara = arabinose $;$ Xyl = xylose $;$ Man = mannose $;$ Glu = glucose $;$ Gal = galactose

y $\mathrm{Mol}$ ratio of total neutral sugar $(\mu \mathrm{mol})$ and total uronic acids amount $(\mu \mathrm{mol})$.

Table 2. Neutral sugar composition of water-soluble uronic acids from avocado treated with 1methylcyclopropene $(1-\mathrm{MCP})$ or $1-\mathrm{MCP}$ and ethylene. Fruit were treated with $1-\mathrm{MCP}\left(0.09 \mu \mathrm{L}^{-1} \mathrm{~L}^{-1}\right.$ for $12 \mathrm{~h}$ ) and stored at $13{ }^{\circ} \mathrm{C}$ for $18 \mathrm{~d}$ and then transferred to $20^{\circ} \mathrm{C}$. Half of the 1 -MCP treated fruit were exposed to ethylene $\left(100 \mu \mathrm{L} \cdot \mathrm{L}^{-1}\right.$ for $12 \mathrm{~h}$ at $\left.20^{\circ} \mathrm{C}\right)$. Values followed by the same letter in a column do not differ significantly according to Duncan's multiple range test $(P<0.05)$.

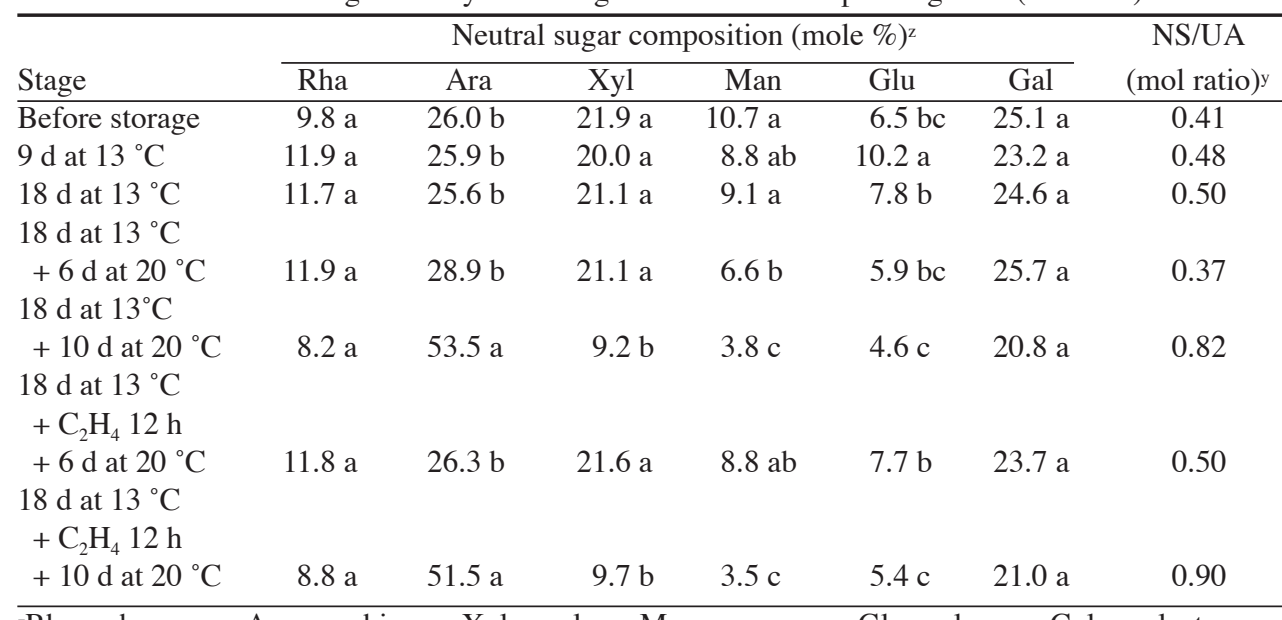

${ }^{2}$ Rha $=$ rhamnose $;$ Ara $=$ arabinose $; \mathrm{Xyl}=$ xylose Man = mannose $;$ Glu = glucose $;$ Gal = galactose

y Mol ratio of total neutral sugar $(\mu \mathrm{mol})$ and total uronic acids amount $(\mu \mathrm{mol})$.

at inhibiting the accumulation of EGase is consistent with other reports for avocado fruit (Feng et al., 2000; Jeong et al., 2002). The inhibition by norbornadiene, a cyclic olefin with action similar to 1-MCP, of EGase transcript induction in avocado mesocarp discs (Starrett and Laties, 1993) provides further evidence for a role of ethylene in EGase accumulation. Differential ethylene responsiveness has been noted for EGases from different tissue sources, for example the suppression of EGase transcripts and activity in red raspberry abscission zones in response to 1-MCP (Lannetta et al., 2000), and enhanced EGase transcript abundance and activity in 'Flavortop' nectarines (Prunus persica) in response to the ethylene antagonist (Dong et al., 2001).

Intervening exposure to ethylene accelerated the characteristic decline of $\beta$-gal in avocado fruit during ripening. These data suggest that ethylene serves as a negative regulator of one or more $\beta$-gal isoenzymes in avocado fruit. The use of cell-free protein extracts in our $\beta$-gal assays would have obscured possible differential responses of specific isozymes. Carey et al. (1995) reported, for example, that total $\beta$-gal activity in tomato fruit remained relatively constant during ripening, whereas the level of one isozyme ( $\beta$-Gal II) increased significantly.

A net loss of pectic-associated neutral sugars occurred during avocado fruit ripening (Tables 1 and 2). Arabinose, galactose, and xylose were the predominant neutral sugars of WSP, consistent with reports for similar pectic fractions from tomato (Gross, 1986), with lower quantities of rhamnose, glucose, and mannose. Dur- ing avocado ripening, a proportional loss in galactose, xylose, mannose, and glucose was observed for both control and 1-MCP-treated fruit. The proportional quantity of galactose in 1-MCP-treated fruit remained high relative to the levels in control fruit at the full-ripe stage. The capacity of avocado $\beta$-gal to deglycosylate native WSP was not measured in our study; however, the marked decline in galactose content of WSP during ripening was much greater in control $(41 \%$ decline) compared with 1-MCP-treated fruit (17\% decline), providing evidence that the enzyme(s) contributing to degalactosidation of WSP and CSP are ethylene-responsive proteins.

The application of ethylene to 1MCP-treated 'Booth 7' avocado fruit upon reaching a mid-ripe stage of development was largely ineffective at facilitating a recovery from the effects of the ethylene-action inhibitor, particularly in terms of fruit firmness. Similarly, treatment of 'Monroe' avocado fruit with exogenous ethylene $\left(100 \mu \mathrm{L} \cdot \mathrm{L}^{-1}\right.$ for $12 \mathrm{~h}$ at $\left.20{ }^{\circ} \mathrm{C}\right)$ before or after 1-MCP treatment did not influence firmness, respiration, or $\mathrm{C}_{2} \mathrm{H}_{4}$ production compared with fruit treated with 1-MCP alone (Jeong and Huber, unpublished). The inability of exogenous ethylene to overcome 1MCP-induced inhibition of ethylene responses is consistent with reports that 1-MCP acts as a high affinity, noncompetitive inhibitor of ethylene action (Feng et al., 2000; Yueming and Jiarui, 2000). While exogenous ethylene does result in the selective recovery of some ripening parameters, including PG and EGase activities in avocado fruit, other features of ripening including firmness and color are much more recalcitrant to the action of exogenous ethylene. It is possible that more prolonged or continuous exposure to ethylene may prove more efficacious in reversing the effects of the ethylene antagonist; however, the results of the present study indicate that the coordinative role of ethylene in the ripening process is to a large extent disrupted irreversibly.

The mechanism of recovery from the effects of $1-\mathrm{MCP}$ on ripening of avocado and other fruits remains unknown. Although receptor replenishment (e.g., through membrane or protein turnover) is typically invoked as an explanation for the eventual ripening of 1-MCP-treated fruits (Feng et al., 2000; Rupasinghe et al., 2000), Sisler et al. (2003) reported recently that cyclopropenes bearing alkyl chains of up to 10 carbon units (1-decylcyoclopropene, 1-DCP) extended by nearly three-fold the green life of bananas compared with similar doses of 1MCP. If these cyclopropenes act in a mechanistically similar fashion (targeted specifically to ethylene receptors), and if increasing chain length does not induce ancillary, indirect effects on ripening, the data indicate that ripening recovery can be explained through a decline in antagonist efficacy as well as receptor replenishment. 


\section{Literature Cited}

Ahmed, A.E. and J.M. Labavitch. 1977. A simplified method for accurate determination of cell wall uronide content. J. Food Biochem. $1: 361-365$.

Albersheim, P., D.J. Nevins, P.D. English, and A. Karr. 1967. A method for the analysis of sugars in plant cell wall polysaccharides by gas-liquid chromatography. Carbohydrate. Res. 5:430-445.

Awad, M. and R.E. Young. 1979. Postharvest variation in cellulase, polygalacturonase, and pectinmethylesterase in avocado (Persea americana Mill. cv. Fuerte) fruits in relation to respiration and ethylene production. Plant Physiol. 64:306-308.

Awad, M. and R.E. Young. 1980. Avocado pectinmethylesterase activity in relation to temperature, ethylene, and ripening. J. Amer. Soc. Hort. Sci. 105:638-641.

Blankenship, S.M. and J.M. Dole. 2003. 1-Methylcyclopropene: Areview. Postharvest Biol. Technol. 28:1-25.

Blumenkrantz, N. and G. Asboe-Hansen. 1973. New method for quantitative determination fo uronic acids. Anal. Biochem. 54:484-449.

Carey, A.T., K. Holt, S. Picard, R. Wilde, G.A. Tucker, C.R. Bird, W. Schuch, and G. B. Seymour. 1995. Tomato exo-(1-4)- $\beta$-D-galactanase. Isolation, changes during ripening in normal and mutant fruit, and characterization of related cDNA clone. Plant Physiol. 108:1099-1107.

Carrington, C.M.S., L.C. Greve, and J.M. Labavitch. 1993. Cell wall metabolism in ripening fruit. VI. Effect of the antisense polygalacturonase gene on cell wall changes accompanying ripening in transgenic tomatoes. Plant Physiol. 103:429-434.

Christofferson, R.E., M.L. Tucker, and G.G. Laties. 1984. Cellulase gene expression in ripening avocado (Persea americana $\mathrm{cv}$. Hass) fruit. The accumulation of cellulase mRNA and protein as demonstrated by cDNA hybridisation and immunodetection. Plant Mol. Biol. 3:385-392.

De Vetten, N.C. and D.J. Huber. 1990. Cell wall changes during the expansion and senescence of carnation (Dianthus caryophyllus) petals. Physiol. Plant. 78:447-454.

Dong, L., H.W. Zhou, L. Sonego, A. Lers, and S. Lurie. 2001. Ethylene involvement in the cold storage disorder of 'flavortop' nectarine. Postharvest Biol. Technol. 23:105-115.

Fan, X., L. Argenta, and J.P. Mattheis. 2000. Inhibition of ethylene action by 1-methylcyclopropene prolongs storage life of apricots. Postharvest Biol. Technol. 20:135-142.

Feng, X., A. Apelbaum, E.C. Sisler, and R. Goren. 2000. Control of ethylene responses in avocado fruit with 1-methylcyclopropene. Postharvest Biol. Technol. 20:143-150.

Gross, K.C. 1986. Composition of ethanol-insoluble polysaccharides in water extracts of ripening tomatoes. Phytochemistry 25:373-376.

Hagerman,A.E. and P.J. Austin. 1986. Continuous spectrophotometric assay for plant pectin methyl esterase. J. Agr. Food Chem. 34:440-444.

Hoeberichts, F.A., H.W. Linus, V.D. Plas, and E.J. Woltering. 2002. Ethylene perception is required for the expression of tomato ripeningrelated genes and associated physiological changes even at advanced stages of ripening. Postharvest Biol. Technol. 26:125-133.

Huber, D.J. and E.M. O'Donoghue. 1993. Polyuronides in avocado (Persea americana) and tomato (Lycopersicon esculentum) fruits exhibit markedly different patterns of molecular weight downshifts during ripening. Plant Physiol. 102:473-480.

Huber, D.J., Y. Karakurt, and J. Jeong. 2001. Pectin degradation in ripening and wounded fruit. Brazilian J. Plant Physiology 13:224-24.

Jeong, J., D.J. Huber, and S.A. Sargent. 2002. Influence of 1-methylcyclopropene (1-MCP) on ripening and cell-wall matrix polysaccharides of avocado (Persea americana) fruit. Postharvest Biol. Technol. 25:241-256

Jeong, J., D.J. Huber, and S.A. Sargent. 2003. Delay of avocado (Persea americana) fruit ripening by 1-methylcyclopropene and wax treatments. Postharvest Biol. Technol. 28:247-257.

Jiang, Y., D.C. Joyce, and A.J. Macnish. 1999. Responses of banana fruit to treatment with 1-methylcycloprpene. Plant Growth Regulat. 28:77-82.

Klee, H. and D. Tieman. 2002. The tomato ethylene receptor gene family: Form and function. Physiol. Plantarum. 115:336-341.
Kramer, M., R. Sanders, H. Bolkan, C. Waters, R.E. Sheehy, and W.R. Hiatt. 1992. Postharvest evaluation of transgenic tomatoes with reduced levels of polygalacturonase: Processing, firmness, and disease resistance. Postharvest Biol. Technol. 1:241-255.

Lannetta, P.P.M., M. Wyman, A. Neelam, C. Jones, M.A. Taylor, H.V. Davies, and R. Sexton. 2000. A Causal role for ethylene and endobeta-1,4-glucanase in the abscission of red-raspberry (Rubus idaeus) drupelets. Physiol. Plantarum 110:535-543.

Lelievre, J.M., A. Latche, B. Jones, M. Bouzayen, and J.C. Pech. 1997. Ethylene and fruit ripening. Physiol. Plantarum 101:727-739.

Lincoln, J.E., S. Cordes, E. Read, and R.L. Fischer. 1987. Regulation of gene expression by ethylene during Lycopersicon esculentum (tomato) fruit development. Proc. Natl. Acad. Sci. 84:2793-2797

Milner, Y. and G. Avigad. 1967. A copper reagent for the determination of hexuronic acids and certain ketohexoses. Carbohydr. Res. 4:359-361.

Pharr, D.M., H.N. Sox, and W.B. Nesbitt. 1976. Cell wall bound nitrophenylglycosidase of tomato fruits. J. Amer. Soc. Hort. Sci. 101:397-400.

Picton, S., S.L. Barton, M. Bonzayen, A.J. Hamilton, and D. Grierson. 1993. Altered fruit ripening and leaf senescence in tomatoes expressing and antisense ethylene forming enzyme transgene. The Plant Journal 3:469-481.

Rupasinghe, H.P.V., D.P. Murr, G. Paliyath, and L. Skog. 2000. Inhibitory effect of 1-MCP on ripening and superficial scald development in 'McIntosh' and 'Delicious' apples. J. Hort. Sci. Biotechnol. 75:271-276.

Sakurai, N. and D.J. Nevins. 1997. Relationship between fruit softening and wall polysaccharides in avocado (Persea americana Mill) mesocarp tissues. Plant Cell Physiol. 38:603-610.

Saltveit, M.E. 1999. Effect of ethylene on quality of fresh fruits and vegetables. Postharvest Biol. and Technol. 15:279-292.

SAS Insititute. 1985. SAS/STAT guide for personal computers. Version 6. SAS Inst., Cary, N.C.

Seymour, G.B. and G.A. Tucker. 1993. Avocado, p. 53-81. In: G.B. Seymour, J. Tayler, and G.A. Tucker (eds.). Biochemistry of fruit ripening. Chapman \& Hall, London.

Sisler, E.C. and M. Serek. 1997. Inhibitors of ethylene responses in plants at the receptor level-Recent developments. Physiol. Plant. 100:577-582.

Sisler, E.C., T. Alwan, R. Goren, M. Serek, and A. Apelbaum. 2003. 1-substituted cyclopropenes: Effective blocking agents for ethylene action in plants. Plant Growth Regulat. 40:223-228.

Smith, P.K., R.I. Krohn, G.T. Hermanson, A.K. Mallia, F.H. Gartner, M.D. Provenzano, E.K. Fujimoto, N.M. Goeke, B.J. Olson, and D.C. Klenk. 1985. Measurement of protein using bicinchoninic acid. Anal. Biochem. 150:76-85.

Starrett, D. and G. Laties. 1993. Ethylene and wound-induced gene expression in the preclimacteric phase of ripening avocado fruit and mesocarp discs. Plant Physiol. 103:227-234.

Theologis, A., L. Wong, W.H. Rottmann, and D.M. Gantz. 1993. Use of a tomato mutant constructed with reverse genetics to study fruit ripening, a complex developmental process. Devel. Genet. 14:282-295

Wakabayashi, K., J.P. Chun, and D.J. Huber. 2000. Extensive solubilization and depolymerization of cell wall polysaccharides during avocado (Persea americana) ripening involves concerted action of polygalacturonase and pectinmethylesterase. Physiol. Plantarum. 108:345-352.

Wakabayashi, K., T. Hoson, and D.J. Huber. 2003. Methyl de-esterification as a major factor regulating the extent of pectin depolymerization during fruit ripening: A comparison of the action of avocado (Persea americana) and tomato (Lycopersiconesculentum) polygalacturonases. J. Plant Physiol. 160:667-673.

Yueming, J. and F. Jiarui. 2000. Ethylene regulation of fruit ripening: Molecular aspects. Plant Growth Regulat. 30:193-200.

Zauberman, G. and M. Schiffmann-Nadel. 1972. Pectin methylesterase and polygalacturonase in avocado fruit at various stages of development. Plant Physiol. 49:864-865.

Zheng, L., C.F. Watson, and D. DellaPenna. 1994. Differential expression of the two subunits of tomato polygalacturonase isoenzyme 1 in wild-type and rin tomato fruit. Plant Physiol. 105:1189-1195. 